\title{
The Study of Dose Distribution according to the Using Linac and Tomotherapy on Total Lymphnode Irradiation
}

\author{
Youngjae Kim, Gwanguk Seol \\ Dept. of Radiological Technology, Gwangyang Health College

\section{선형가속기와 토모치료기를 이용한 전림프계의 방사선 치료시 선량분포에 관한 연구}

\author{
김영재, 설광욱
}

광양보건대학교 방사선과

\begin{abstract}
In this study, compare and analyze the dose distribution and availability of radiation therapy when using a different devices to TNI(Total Lymphnodal Irradiation). Test subjects(patients) are 15 people(Male 7, Female 8). Acquire CT Simulation images of the 15 people using Somatom Sansation Open 16 channel and then acquired images was transferred to each treatment planning system Pinnacle Ver 8.0 and Tomotherapy Planning System and separate the tumor tissue and normal tissues(whole lung, spinal cord, Rt kidney, Lt kidney). Tumor prescription dose was set to 750 cGy. and then Compare the Dose Compatibility, Normal Tissue's Absorbed Dose, Dose Distribution and DVH. Statistical analysis was performed SPSS Ver. 18.0 by paired sample Assay. The absorbed dose in the tumor tissue was $751.0 \pm 4.7 \mathrm{cGy}$ in tomotherapy planning, $746.9 \pm 14.1 \mathrm{cGy}$ in linac. Tomotherapy's absorbed dose in the tumor was more appropriate than linac. and These values are not statistically significant( $p>0.05)$. Tomotherapy plan's absorbed dose in the normal tissues were less than linac's plan. This value was statistically significant $(\mathrm{p}<0.05)$ excepted of whole lung. In $\mathrm{DVH}$, appropriated on tumor and normal tissues in tomotherapy and linac but tomotherapy's TER was better than linac. Namely, a result of Absorbed dose in tumor and normal tissue, Dose distribution pattern, DVH, Both radiation therapy devices were appropriated in radiation therapy on TER. The Linac has a short treatment time(about 15-20 $\mathrm{min}$ ) and open space on treatment time. It cause infant and pediatric patients to receiving uncomfortable treatment. So, In this case, it will be fine that Linac based therapy was restricted use. and if the patient was cooperative, it will be show a better prognosis that Tomotherapy using Radiation Therapy.
\end{abstract}

Key Words : TLI, Radiation Therapy, Tomotherpy, Dose Distribution

\section{요 야}

전림프계의 방사선치료시 선형가속기와 토모테라피를 이용하여 치료계획 수립 시 유용성을 확인하였다. 실험에 동 의한 실험대상자 15명(남: 7명, 여: 8명)의 모의치료영상을 Somatom Sansation Open 16 channel으로 획득하여 이를 
각각 의료용 선형가속기 치료계획 장치와 토모테라피 치료계획 장치로 전송하고 종양체적과 정상조직(전체 폐, 척수, 우측신장, 좌측신장)을 구분하여 종양조직에 $750 \mathrm{cGy}$ 를 설정하여 종양조직의 선량 적합성, 정상조직의 선량흡수정도, 선량분포양상 그리고 선량체적곡선을 비교하여 평가하였으며 SPSS Ver. 18.0을 이용하여 대응표본검정을 실시하였 다. 종양의 흡수선량 측정결과 토모테라피의 경우 $751.0 \pm 4.7 \mathrm{cGy}$, 선형가속기는 $746.9 \pm 14.1 \mathrm{cGy}$ 의 선량을 보였 으며 이는 통계적으로 유의하지 않았다(p>0.05). 정상조직의 경우 전체 폐, 척수, 우측신장, 좌측신장에 입사되는 평 균 방사선량은 토모테라피가 선형가속기보다 다소 낮은 방사선 흡수량을 보였다. 선량체적곡선에서 종양조직 및 정상 조직 모두 적합한 양상을 보였다. 즉, 종양 및 정상조직의 선량흡수정도, 선량분포양상, 선량체적 곡선을 살펴본 결과 모두 적합한 치료효과비를 보인 것으로 판단되며 토모테라피 치료가 다소 높은 치료효율을 보였다. 토모테라피를 이용 한 치료는 폐쇄형 치료공간과 긴 치료시간의 단점이 있기 때문에 오랜시간 자세재현이 불가능한 환자의 경우, 제한적 으로 선형가속기 치료를 실시하여도 무방할 것으로 판단된다.

중심단어: 방사선치료, 토모테라피, 선량분포

\section{I. 서 론}

전체 림프계(Total Nymph node)를 방사선으로 치료 하는 것은 재생불량성 빈혈(Aplastic anemia)환자를 치 료하는 데 유용하게 적용할 수 있다. 재생불량성 빈혈 의 치료시 동종조혈모세포(AlloPBSCT)를 이식하여야 하며 성공적인 치료결과를 얻기 위해서 환자의 면역 체계를 억제하여야 한다 ${ }^{[1]}$. 이를 위하여 항암요법 (chemo therapy)과 방사선요법(radiation therapy)을 실시 하게 된다. 항암요법으로는 환자의 면역 억제를 위한 2차 동종조혈모세포 이식의 전처치로 3 일간 항흉선세 포 글리불린(anti-thymocyteglobulin, ATG)을 투여 한 후 익일 $750 \mathrm{cGy} / 1 \mathrm{fx}$ 전체 림프계 조사(Total Nodal Irradiation, TNI)을 시행한다.

전신의 림프절을 치료할 경우 조사야의 겹침오류로 인한 과선량영역(hot spot) 또는 선량부족영역(cold spot)이 발생할 수 있다. 이는 향후 부작용의 발생이나 재발의 위험성을 내포하며 조혈모세포 이식시 거부반 응을 일으킬 수 있다 ${ }^{[2]}$. 따라서 본 논문에서는 동일한 환자들을 대상으로 선형가속기(Linac)와 토모테라피 (Tomotheapy)를 이용한 치료방법을 적용하여 치료의 유용성을 종양조직(tumor tissue)에 입사되는 처방선량, 정상조직(Normal tissues) - 전체 폐(Whole Lung), 척수 (Spinal Cord), 좌·우 콩핕(Lt and Rt Kidney)-의 흡수선 량, 선량분포곡선, 선량체적곡선(DVH, Dose Volume Histogram)을 이용하여 치료기의 종류에 따른 선량분 포의 유용성을 평가하고자 한다.

\section{II. 실험 대상 및 방법}

\section{1. 실험대상}

2013년 1월부터 5월까지 S병원에서 전림프계 방사 선치료를 대상으로 하는 환자 15명을 대상으로 하였으 며 연구목적에 동의하지 않은 환자는 제외하였 다.(Table 1)

Table 1. Patient characteristics

\begin{tabular}{cc}
\hline \multirow{2}{*}{ Characteristic } & Subject \\
\cline { 2 - 2 } & $\mathrm{N}(\%)$ \\
\hline Sex & $7(46.7)$ \\
Male & $8(53.3)$ \\
Female & \\
\hline Age & $2(13.3)$ \\
$>51$ & $8(53.3)$ \\
$41 \sim 50$ & $4(26.6)$ \\
$31 \sim 40$ & $1(6.6)$ \\
$30 \leq$ & $15(100)$ \\
\hline Total &
\end{tabular}

\section{2. 실험방법}

\section{1 실험기기}

의료용 선형가속기로는 Siemens 사의 Artiste CT vision을 이용하였으며 토모테라피 치료는 Tomotheapy Hi-art system 2.0 (Medison, USA)를 이용하였다. 실험대 상자의 컴퓨터 단층 모의치료영상은 Siemens의 
Somaton Sensation Open 을 이용하여 $5 \mathrm{~mm}$ 의 단편두께 의 $\mathrm{CT}$ 영상을 얻었으며 치료계획 장치로는 의료용선형 가속기의 경우 Philip 사의 Pinacle Ver. 8.0 을 이용하여 치료계획을 실시하였고 토모테리피 치료계획으로는 Tomotherapy planning system을 이용하여 치료계획을 실시하였다.

\section{2 실험과정}

실험과정으로는 각 환자의 컴퓨터 단층 모의치료영 상을 바탕으로 육안적 종양체적(GTV, Gross Tumor Volume)을 정의하였고, 이를 기준으로 $3 \mathrm{~mm}$ 의 여유면 적을 설정하여 치료계획용적(PTV, Planning Target Volume)을 결정하였다. 처방선량은 치료계획용적에 $750 \mathrm{cGy}$ 의 흡수선량이 되도록 설정하였으며 선형가속 기의 경우 $6 \mathrm{MV}$ 의 엑스선을 이용하여 대향 2 문 조사 법으로 실시하였으며 토모테라피의 경우 Pitch 값을 0.3 , Modulator 값은 2.0, 치료단면두께는 $10 \mathrm{~mm}$ 로 설 정하였다.

\section{3 평가방법}

2가지의 서로 다른 치료기의 종류-선형가속기 (Linac), 토모테라피(Tomotheapy)-에 따라 치료계획용적 (PTV, Planning Target Volume)에 입사되는 선량-치료계 획 후 영상에서 얻을 수 있는 선량과 처방선량의 오 차율의 변화와 정상조직(Normal tissues)-폐(Whole Lung), 척수(Spinal Cord), 콩팥(Kidney)-의 최대·최소 및 평균흡수선량, 두 치료법의 선량분포곡선양상을 비 교하고, 선량체적곡선(DVH, Dose Volume Histogram)을 이용하여 유용성을 비교·평가하였다.

\section{4 통계분석}

본 실험에서 얻은 자료정보의 통계처리는 SPSS Ver.
18.0 을 이용하여 실시하였으며 분석의 방법은 $\mathrm{t}$ 검정 을 통한 대응표본검정의 방법을 이용하였다. 통계분석 결과 유의확률이 0.05 미만 $(\mathrm{p}<0.05$ )일 경우 통계적 으로 유의하다고 설정하였다.

\section{III. 결 과}

\section{1. 종양조직의 흡수선량 평가}

종양조직의 흡수선량을 살펴보면 임상적 치료용적 (CTV)에서는 선형가속기의 경우 최소선량 $\left(\mathrm{D}_{\min }\right)$ 은 56.2 $\pm 3.5 \mathrm{cGy}$, 토모테라피는 $678.6 \pm 1.5 \mathrm{cGy}$ 의 선량값을 보였으며 최대선량 $\left(\mathrm{D}_{\max }\right)$ 은 각각 $799.4 \pm 2.5 \mathrm{cGy}, 815.0$ $\pm 1.1 \mathrm{cGy}$ 이었다. 평균값 $\left(\mathrm{D}_{\text {mean }}\right)$ 은 의료용 선형가속기 의 경우 $705.9 \pm 16.5 \mathrm{cGy}$ 이었고 토모테라피는 $786.3 \pm$ $5.2 \mathrm{cGy}$ 의 선량값을 나타냈다. 치료계획용적(PTV)에서 선형가속기와 토모테라피 치료의 경우 최소선량 $\left(\mathrm{D}_{\min }\right)$ 은 $39.2 \pm 6.2 \mathrm{cGy}, 489.4 \pm 2.5 \mathrm{cGy}$, 최대선량 $\left(\mathrm{D}_{\max }\right)$ 값은 $807.3 \pm 3.1 \mathrm{cGy}, 782.1 \pm 1.5 \mathrm{cGy}$, 평균값 $\left(\mathrm{D}_{\text {mean }}\right)$ 은 746.9 $\pm 14.1 \mathrm{cGy}, 751.0 \pm 4.7 \mathrm{cGy}$ 의 선량값을 보여 처방선 량인 $750 \mathrm{cGy}$ 에 근접하였다. 이들의 $\mathrm{p}$ 값은 0.359로 통 계적으로 유의하지 않았다(Table 2).

\section{2. 정상조직의 흡수선량 평가}

\section{가. 전체 폐(whole Lung)에 흡수되는 방사선량}

전체 폐에 흡수되는 선량을 측정한 결과 의료용 선 형가속기의 경우에는 최소선량 $\left(\mathrm{D}_{\min }\right)$ 은 $27.3 \pm 0.5 \mathrm{cGy}$, 최대선량 $\left(\mathrm{D}_{\max }\right)$ 은 $794.8 \pm 0.6 \mathrm{cGy}$ 이었고 평균 $\left(\mathrm{D}_{\text {mean }}\right)$ $296.0 \pm 6.2 \mathrm{cGy}$ 의 선량흡수를 보였다. 토모테라피의 경우 최소선량 $\left(\mathrm{D}_{\min }\right)$ 이 $61.7 \pm 1.5 \mathrm{cGy}$, 최대선량 $\left(\mathrm{D}_{\max }\right)$ 은 $775 \pm 3.6 \mathrm{cGy}$ 였으며 평균선량 $\left(\mathrm{D}_{\text {mean }}\right)$ 은 $307.2 \pm 9.3$

Table 2. Absorb Dose of Tumor and Normal Tissues (Unit : cGy)

\begin{tabular}{|c|c|c|c|c|c|c|}
\hline & \multicolumn{2}{|c|}{ Min dose(cGy) } & \multicolumn{2}{|c|}{ Max dose(cGy) } & \multicolumn{2}{|c|}{ Mean dose(cGy) } \\
\hline & Linac & Tomotherapy & Linac & Tomotherpy & Linac & Tomotherapy \\
\hline CTV & $56.2 \pm 3.5$ & $678.6 \pm 1.5$ & $799.4 \pm 2.5$ & $815.0 \pm 1.1$ & $705.9 \pm 16.5$ & $786.3 \pm 5.2$ \\
\hline PTV & $39.2 \pm 6.2$ & $489.4 \pm 2.5$ & $807.3 \pm 301$ & $782.1 \pm 1.5$ & $746.9 \pm 14.1$ & $751.0 \pm 4.7$ \\
\hline Spinal Cord & $28.5 \pm 0.3$ & $192.3 \pm 2.2$ & $800.2 \pm 2.4$ & $504.2 \pm 4.1$ & $638.5 \pm 5.1$ & $259.8 \pm 3.4$ \\
\hline Total Lung & $27.3 \pm 0.5$ & $61.7 \pm 1.5$ & $794.8 \pm 0.6$ & $775.0 \pm 3.6$ & $296.0 \pm 6.2$ & $307.2 \pm 9.3$ \\
\hline Rt. Kidney & $33.0 \pm 2.15$ & $45.5 \pm 1.8$ & $750.1 \pm 3.3$ & $678.1 \pm 1.5$ & $280.4 \pm 2.6$ & $213.8 \pm 1.8$ \\
\hline Lt. Kidney & $38.0 \pm 0.25$ & $47.3 \pm 2.7$ & $758.6 \pm 2.8$ & $758.2 \pm 3.8$ & $268.3 \pm 3.5$ & $287.4 \pm 2.6$ \\
\hline
\end{tabular}


$\mathrm{cGy}$ 로 나타났으며 $\mathrm{p}$ 값은 0.322 로 통계적으로 유의하 지 않았다(Table 2).

\section{나. 척수(Spinal cord)에 흡수되는 방사선량}

선형가속기의 경우에는 최소선량 $\left(\mathrm{D}_{\min }\right)$ 은 $28.5 \pm 0.3$ $\mathrm{cGy}$, 최대선량 $\left(\mathrm{D}_{\max }\right)$ 은 $800.2 \pm 2.4 \mathrm{cGy}$ 이었고 평균 (D $\left.\mathrm{D}_{\text {mean }}\right) 638.5 \pm 5.1 \mathrm{cGy}$ 의 선량흡수를 보였다. 토모테 라피의 경우 최소선량 $\left(\mathrm{D}_{\min }\right.$ 이 $192.3 \pm 2.2 \mathrm{cGy}$, 최대선 량 $\left(\mathrm{D}_{\max }\right)$ 은 $504.2 \pm 4.1 \mathrm{cGy}$ 였으며 평균선량 $\left(\mathrm{D}_{\operatorname{mean}}\right)$ 은 $259.8 \pm 3.4 \mathrm{cGy}$ 로 나타났으며 $\mathrm{p}$ 값은 0.001로 통계적 으로 유의한 결과를 보였다(Table 2).

\section{다. 콩팥(Kidney)에 흡수되는 방사선량}

선형가속기의 최소선량 $\left(\mathrm{D}_{\min }\right)$ 은 좌 · 우 각각 $38 \pm$ $0.25 \mathrm{cGy}, 33 \pm 2.15 \mathrm{cGy}$ 최대선량 $\left(\mathrm{D}_{\max }\right)$ 은 각각 $758.6 \pm$ $2.8 \mathrm{cGy}, 750.1 \pm 3.3 \mathrm{cGy}$ 이었고 평균 $\left(\mathrm{D}_{\text {mean }}\right)$ 흡수선량 은 각각 $268.3 \pm 3.5 \mathrm{cGy}, 280.4 \pm 2.6 \mathrm{cGy}$ 의 선량흡수 를 보였다. 토모테라피는 좌 - 우 콩팥 각각 최소선량 $\left(\mathrm{D}_{\min }\right) 47.3 \pm 2.7 \mathrm{cGy}, 45.5 \pm 1.8 \mathrm{cGy}$ 최대선량 $\left(\mathrm{D}_{\max }\right)$ 은 각각 $758.2 \pm 3.8 \mathrm{cGy}, 678.1 \pm 1.5 \mathrm{cGy}$ 였으며 평균선 량 $\left(\mathrm{D}_{\text {mean }}\right)$ 은 $287.4 \pm 2.6 \mathrm{cGy}, 213.8 \pm 1.8 \mathrm{cGy}$ 로 나타났

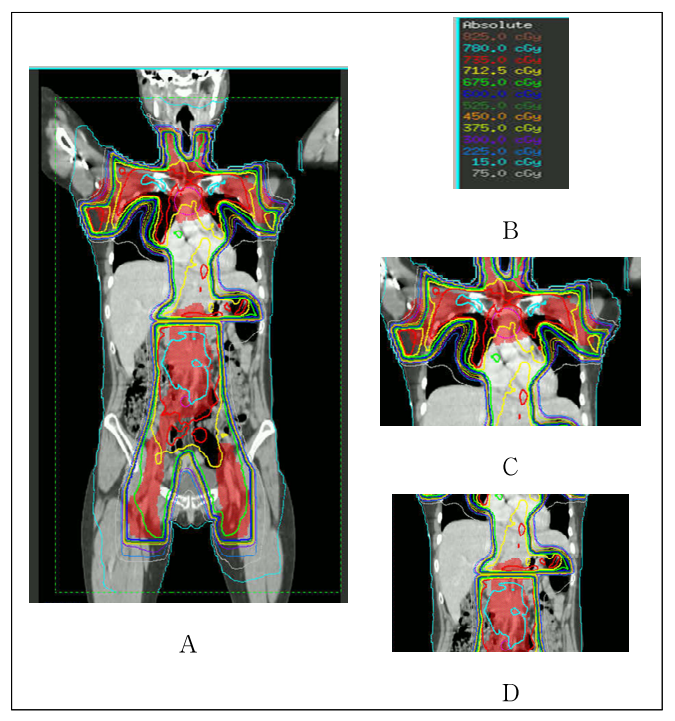

Figure 1. Linac Based of TNI Dose Distribution Curve (A: Overall shape, B: Absorbed Dose, C: Upper lung region, $\mathrm{D}$ : Adjoining field area region)
으며 $\mathrm{p}$ 값은 각각 0.002 와 0.001 으로 통계적으로 유의 성을 확보하였다(Table 2).

\section{2. 선량분포양상 분석}

선형가속기과 토모테라피의 선량윤곽을 관찰해보면 토모테라피의 선량분포가 종양조직(PTV)를 적합하게 Cover 하는 모습을 관찰 할 수 있었다(Fig 1-A, 2-A). 세 부적으로 관찰해보면 선형가속기의 경우 폐의 상방 (Upper lung region)에 선량이 흡수됨이 확인 할 수 있 지만(Fig 1-C), 토모테라피의 경우 폐의 전체적인 부위 의 과도한 방사선 흡수량은 발견할 수 없었다(Fig 2-C). 이는 방사선치료 후 부작용 발생유무를 확인 해 볼 필 요가 있을 것이다.

선형가속기의 경우 조사야는 횡축과 종축이 최대 $40 \mathrm{~cm}$ 의 영역으로 전체 림프계를 치료함에 있어 한계 점이 있다. 따라서 상반신과 하반신으로 조사부위를 나누어 치료하게 되는데 두 개의 조사야가 겹치는 부 위가 정확하지 않으면 선량 부족 혹은 과다선량이 발 생하여 해당부분의 종양조직이나 정상조직에 적합하 지 않은 선량이 전달 될 수 있다(Fig 1-D). 반면 CT의 원리로 치료를 시행하는 토모테라피는 조사야의 제한 이 없으므로 선형가속기에서 볼 수 있었던 복부부위

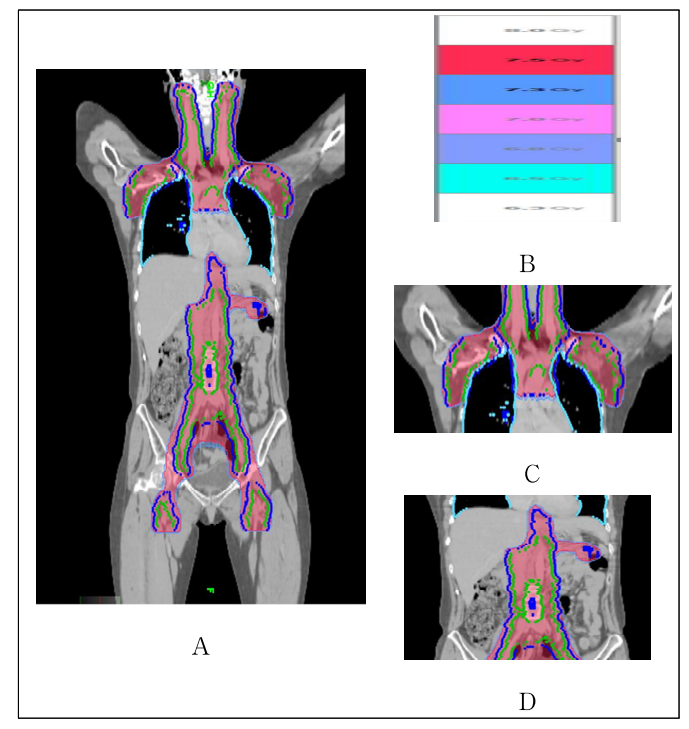

Figure 2. Tomotherapy Based of TNI Dose Distribution Curve (A: Overall shape, B: Absorbed Dose, C: Upper lung region, D: Adjoining field area region) 
의 부적합한 선량 문제(hot spot or cold spot)가 나타나 지 않는다(Fig 2-D).

치료시간을 살펴보면 의료용 선형가속기를 이용하 여 치료를 할 경우 환자에게 4문 조사(4-portal irradiation)를 실시하게 되는데 이 때 걸리는 시간은 환 자의 위치잡이(Set-up)까지 고려해 본다면 평균 20 분의 시간이 걸리게 되므로 평균 4 문 조사 방사선치료시간 인 15 분과 비교해 보았을 경우 큰 차이가 나지 않았다. 하지만 토모테라피는 선형가속기보다 2.5 배 정도 긴 치료시간인 40 분 이상의 치료시간이 소요된다. 또한 개방적인 공간에서 치료를 받을 수 있는 선형가속기 와 비교해 볼 때 토모테라피는 페쇄적인 치료공간으 로 폐쇄공포증을 가진 환자는 치료받기 힘들 것으로 예상된다. 그러므로 토모테라피로 전림프계치료를 할 경우 폐쇄공포증 환자나 자세의 고정이 힘든 유·소아 환자 등에서는 치료법을 적용하는데 있어 일부 제한 적일 수 있다.

\section{3. 선량체적곡선(DVH, Dose Volume Histogram) 의 비교}

선형가속기의 경우 선량체적곡선(DVH)을 살펴보면 종양용적(PTV)의 $\mathrm{V}_{95}$ (체적의 $95 \%$ 이상 흡수되는 선량) 는 $530 \mathrm{cGy}$ 이고 $\mathrm{V}_{90}$ 은 $650 \mathrm{cGy}, \mathrm{V}_{75}$ 는 $700 \mathrm{cGy}$ 로 나타 났다. 정상조직의 경우 전체 폐는 $\mathrm{V}_{70}$ 은 $200 \mathrm{cGy}, \mathrm{V}_{60}$ 은 $400 \mathrm{cGy}, \mathrm{V}_{30}$ 은 $730 \mathrm{cGy}$ 의 흡수선량이 나타났다. 척수 의 경우 $\mathrm{V}_{90}$ 은 $50 \mathrm{cGy}, \mathrm{V}_{80}$ 은 $520 \mathrm{cGy} \mathrm{V}_{30}$ 은 $750 \mathrm{cGy}$ 의 흡수량을 보였으며 좌측과 우측의 콩팥에서의 방사선 흡수량은 좌측의 경우 $\mathrm{V}_{50}$ 은 $500 \mathrm{cGy}, \mathrm{V}_{30}$ 은 $720 \mathrm{cGy}$, 우 측의 경우 $\mathrm{V}_{50}$ 은 $100 \mathrm{cGy} \mathrm{V}_{30}$ 은 $600 \mathrm{cGy}$ 의 선량이 나타 났다.(Fig 3) 토모테라피의 경우 종양용적(PTV)의 $\mathrm{V}_{95}$ 는

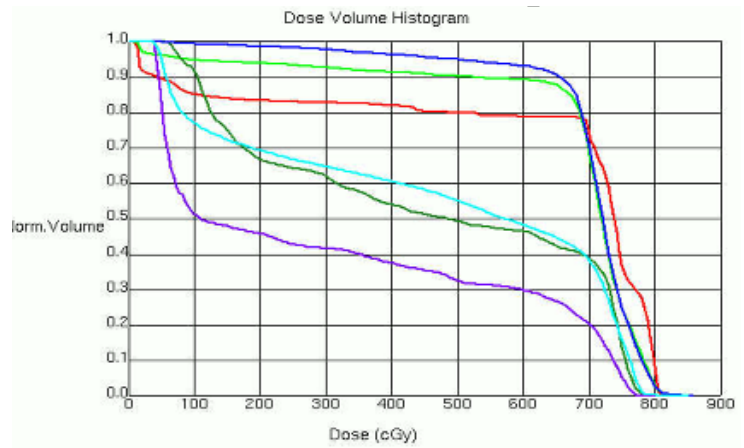

Figure 3. Linac Based DVH of TNI
$750 \mathrm{cGy}$ 이고 $\mathrm{V}_{90}$ 은 $760 \mathrm{cGy}, \mathrm{V}_{75}$ 는 $771 \mathrm{cGy}$ 로 나타났 다. 정상조직의 경우, 전체 폐에 흡수되는 선량은 $\mathrm{V}_{70}$ 의 경우 $365 \mathrm{cGy}, \mathrm{V}_{60}$ 은 $370 \mathrm{cGy}, \mathrm{V}_{30}$ 은 $380 \mathrm{cGy}$ 의 흡수 선량을 보였다. 척수의 경우 $\mathrm{V}_{90}$ 은 $330 \mathrm{cGy}, \mathrm{V}_{80}$ 은 350 $\mathrm{cGy} \mathrm{V}_{30}$ 은 $385 \mathrm{cGy}$ 의 흡수량을 보였으며 좌측과 우측 의 콩팥에서의 방사선흡수량은 좌측의 경우 $\mathrm{V}_{50}$ 은 300 $c G y, V_{30}$ 은 $350 \mathrm{cGy}$, 우측의 경우 $\mathrm{V}_{50}$ 은 $235 \mathrm{cGy} \mathrm{V}_{30}$ 은 $300 \mathrm{cGy}$ 의 선량이 나타났다(Fig 3, 4, Table 3).

\section{$\mathrm{V}$. 고 찰}

재생불량성 빈혈(Aplastic anemia)환자의 치료는 항암 제와 방사선 치료를 병행하여 시행하였을 경우 환자 의 생존율은 전 림프계 조사를 단독 시행할 때 보다 약 30\% 이상의 치료 효과를 보인다고 보고되며 ${ }^{[3]}$ 이 때 사용하는 방사선발생장치료는 선형가속기와 토모 테라피가 주로 사용되고 있다. 이에 본 논문에서는 방 사선 치료시 치료기의 종류-선형가속기, 토모테라피에 따라 치료효율성을 분석하였다.

종양조직과 정상조직의 흡수선량을 분석한 결과 선 형가속장치와 토모테라피 치료에서 종양조직의 흡수 선량은 각각 $746.9 \pm 14.1 \mathrm{cGy}, 751.0 \pm 4.7 \mathrm{cGy}$ 의 선량 을 보여 처방선량의 오차범위인 $-5 \sim+3 \%$ 의 범위를 만 족하였다. 또한 이 값의 $\mathrm{p}$ 값은 통계적으로 유의하지 않아 치료기의 종류에 따라 종양조직에 흡수되는 선 량값은 큰 연관성이 없었다. 이명자 등의 연구에 의하 면 종양조직에 대한 정확한 처방선량의 전달은 재발 의 위험성을 낮추며 이를 만족하지 못한 치료는 차후 에 재발할 수 있다고 경고하였다 ${ }^{[4]}$. 정상조직(선형가속 기, 토모테라피)의 경우 전체 폐(296.0 $\pm 6.2 \mathrm{cGy}, 307.2$

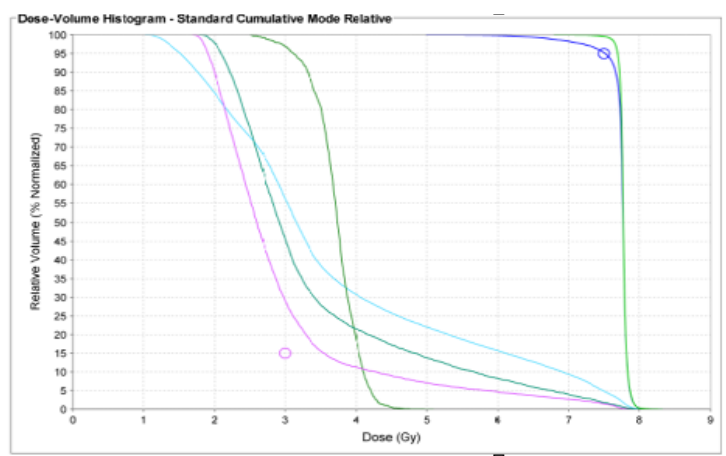

Figure 4. Tomotherpy Based DVH of TNI 
$\pm 9.3 \mathrm{cGy})$, 척수 $(638.5 \pm 5.1 \mathrm{cGy}, 259.8 \pm 3.4 \mathrm{cGy})$, 우 측신장 $(280.4 \pm 2.6 \mathrm{cGy}, 213.8 \pm 1.8 \mathrm{cGy})$, 좌측신장 $(268.3 \pm 3.5 \mathrm{cGy}, 287.4 \pm 2.6 \mathrm{cGy})$ 모두 정상조직 견딤 선량(폐(TD5/5): $1750 \mathrm{cGy}$, 척수(TD5/5): $4700 \mathrm{cGy}$, 신 장(TD5/5): $2300 \mathrm{cGy}$ )과 비교해보았을 때 적은 선량을 나타냈으며 토모테라피 치료기법을 적용할 경우 방사 선흡수량이 선형가속기보다 낮았다. 특히, 각 조직의 최소선량은 그 값이 급격하게 차이를 보였는데 이는 선형가속기의 경우 4 문 조사로서 임의의 부위에 1 차적 선량이 주로 흡수 되었지만 토모테라피의 경우 원형 으로 조사를 함으로써 1 차선 외의 산란선도 임의의 부 위에 영향을 끼친 것으로 보인다. 즉, 토모테라피의 선 량균일성이 더 우수하다는 것을 나타낸다. 정상조직에 선량이 과다부여되면 척수의 경우 일시적인 하지신경 마비, 영구적 손상을 일으킬 수 있고단 신장은 단백뇨 를 발생시킬 수 있으며 기능손실을 초래하고 심할 경 우 기능의 정지를 초래하게 된다[ ${ }^{[]}$. 폐의 경우 방사성 폐렴에 노출될 수 있으며 폐경색, 섬유화를 일으킬 수 있담] 본 연구결과 모두 정상조직 방호측면에 만족하 였으며, 토모테라피를 이용한 치료기법이 선형가속기 를 이용한 치료기법보다 정상조직의 방사선방어 측면 에서 우수한 결과를 보여 토모테라피로 치료를 수행 하는 것이 다소 유용할 것으로 생각된다.

접합부의 간격에 고선량 영역(Hot spot)이나 저선량 영역(Cold spot)이 발생할 수 있어 그에 따른 부작용을 감수해야 하는 문제점이 발생한다. 반면 토모치료기를 이용한 전 림프계 조사의 경우 환자의 전신을 단층으 로 치료할 수 있고, 넓은 영역의 치료가 가능하여 선 형가속기와 같은 문제점의 발생을 방지할 수 있으며 선량 분포 면에서도 선형가속기에 비해 균등한 효과
를 얻을 수 있다. L Z. Nisce 등의 연구에 의하면 인접 영역의 선량과다 혹은 선량부족은 암을 재발이나 정 상조직에 과다피폭을 야기시켜 부작용을 발생시킨다 고 경고 ${ }^{[8]}$ 하였으므로 겹침영역의 선량오류를 피하기 위해서는 토모테라피의 치료기법을 적용하는 것이 치 료효과를 높일 것으로 기대할 수 있다.

선량체적곡선(DVH, Dose Volume Histogram)을 분석 해 보면 종양의 체적에 선형가속기와 토모테라피의 $\mathrm{V}_{95}$ 는 각각 $530 \mathrm{cGy}, 750 \mathrm{cGy}$ 로 토모테라피의 선량적 합도가 높은 것으로 나타났다. 정상조직의 선량흡수정 도를 관찰한 결과 체적에 부여된 선량을 그래프로 분 석해 본 결과 폐는 $\mathrm{V}_{30}$ 이 각각 $730 \mathrm{cGy}, 380 \mathrm{cGy}$ 의 선 량을 보여 토모테라피가 더 적은 선량흡수를 보인 것 으로 관찰되었다. 척수와 좌우측 콩팥의 경우도 모두 토모테라피의 선량흡수량이 더 적은 것으로 나타났다. 즉, 선량체적곡선을 분석한 결과 토모테라피의 선량분 포가 더 적합한 것으로 나타났다.(Table 3)

치료시간을 비교해 보면 선형가속기의 경우 평균 20 분 정도이며 토모테라피는 평균 40 분 이상으로 선형 가속기보다 약 2.5 배 더 소요되는 것으로 예상된다. 이 는 장시간 치료자세를 고정하기 힘든 환자나 유소아 환자의 경우 적용이 제한적이며 토모테라피 치료공간 (Bore Size)은 약 $50 \mathrm{~cm}$ 로 폐쇄공포증 환자에게 적용하 기 불리하다. 치료시간의 차이와 치료제한에 대한 기 존의 연구에서도 이러한 부분을 언급하였으며 정상조 직의 흡수선량이 견딤선량 이하이고 종양조직에 적합 한 선량이 부여된다면 환자 중심적인 치료법을 적용 하는 것이 유리할 수 있다고 하였다[].

본 논문의 제한점으로는 실제로 환자에게 직접 선 량을 전달할 경우 모의치료선량과 실제 선량의 정확

Table 3. The Analysis Radiation Therapy Planning's DVH(Dose Volume Histogram) of Linac and Tomotherapy on TNI(Total Lymphnodal Irradiation) (Unit: cGy)

\begin{tabular}{|c|c|c|c|c|c|c|c|c|c|c|c|c|c|}
\hline & \multicolumn{3}{|c|}{ PTV } & \multicolumn{3}{|c|}{ Whole Lung } & \multicolumn{3}{|c|}{ Spinal cord } & \multicolumn{2}{|c|}{ Rt Kidney } & \multicolumn{2}{|c|}{ Lt Kidney } \\
\hline & $V_{95}$ & $V_{90}$ & $V_{75}$ & $V_{70}$ & $V_{60}$ & $V_{30}$ & $V_{90}$ & $V_{80}$ & $V_{30}$ & $V_{50}$ & $V_{30}$ & $V_{50}$ & $V_{30}$ \\
\hline Linac & 530 & 650 & 700 & 200 & 400 & 730 & 50 & 520 & 750 & 100 & 600 & 500 & 720 \\
\hline Tomotherapy & 750 & 760 & 771 & 365 & 370 & 380 & 330 & 350 & 385 & 235 & 300 & 300 & 350 \\
\hline
\end{tabular}


"Journal of the Korean Society of Radiology, Volume 7, Number 4"

성의 확보를 확인해봐야 할 것으로 사료되며 이러한 환자들의 향후 치료효과의 추적 관찰이 필요할 것이 다. 또한 일반 선형 가속기로 회전단층치료가 가능한 Arc Therapy 치료법이 임상에서 소개되고 있어 이 치 료법과 토모테라피 치료법을 비교 분석하는 것 또한 향후 연구해 볼 필요가 있겠다.

\section{$\mathrm{V}$. 결 론}

전림프계 조사 시 선형가속기와 토모테라피의 치료 계획을 비교한 결과 종양조직에 적합한 선량이 흡수 되었으며 정상조직 흡수선량 및 선량체적곡선을 비교 한 결과 모두 정상조직 견딤선량을 초과하지 않았다.

토모테라피를 이용하여 치료할 경우 조사야의 겹침 이 없어 조사야 내의 과선량 혹은 선량부족영역을 피 할 수 있었지만 오랜 시간 밀폐된 공간에서 치료를 받 기 때문에 특정 환자에게 적용하기 불리한 면이 있다. 따라서 이러한 경우에 제한적으로 선형가속기 치료를 적용하여도 무방할 것으로 사료된다.

\section{참고문헌}

[1] Peterm Auch, Robertg Oodmamn, et al. An Evaluatoion of Total Nodal Irradiation as Treatment for Stage I11 A Hodgkin's Disease. Cancer, Vol. 43, pp. 1255-1261, 1979

[2] 조문준 et al, 비인강암의 방사선치료성적, 대한방사선종양학회지, Vol. 19., No. 1, pp. 9-15, 2001.

[3] Arilyn Weigenberg, Shoshana Morecki, et al. Suppression of Cell-Mediated Immune Responces after Total Lymphoid Irradiation(TLI) I. Characterization of Suppressor Cells of the Mixed Lymphocyte Reaction. Immunology, pp. 132, 1984

[4] 이명자, 전하정, 인강암의 방사선치료성적, 대한방사선종양학회지, Vol 21 No. 4, pp 269 275, 2003.

[5] Ann J, McCunniff et al. Radiation tolerance of the cervical spinal cord. Int Jour Radio Oncol, Vol. 16, No. 3, pp. 675-678, 1988

[6] Micheal $\mathrm{T}$ et al, Normal Tissue Tolerance Dose Metrics for Radiation Therapy of Major Organs. Semin Radiat Oncol, Vol. 17, pp. 131-140, 2007

[7] Marks LB, Munley MT, Bentel GC et al, Physical and biological predictors of changes in whole lung function following thoracic irradiation. Int J Radiat Oncol Biol Phys, Vol. 39, No. 3, pp. 563-570, 1997
[8] L Z. Nisce, M., W. Geller, M.D. et al. Experience with a new technique for "total node" irradiation Hodgkin's disease. British Journal of Radiology, Vol. 47, pp. 108-111, 1974

[9] 송종남, 김영재, 홍성일, The Usability of 3D-CRT, IMRT, Tomotherapy Radiation Therapy on Nasopharyngeal Cancer, JKSR, Vol. 6, No. 5, pp. 365-371, 2012. 